\title{
Education and the Arts: Educating Every Child in the Spirit of Inquiry and Joy
}

\author{
Mariale M. Hardiman \\ School of Education, Johns Hopkins University, Baltimore, USA \\ Email:mmhardiman@jhu.edu
}

Received 16 July 2016; accepted 23 August 2016; published 26 August 2016

Copyright (C) 2016 by author and Scientific Research Publishing Inc.

This work is licensed under the Creative Commons Attribution International License (CC BY). http://creativecommons.org/licenses/by/4.0/

c) (i) Open Access

\begin{abstract}
This paper explores the political and social forces that have led to the well-documented narrowing of the curriculum, squeezing out arts programming in schools. While not intended to be an exhaustive literature review, this work highlights important findings that correlate arts learning with biological changes as well as cognitive and academic advantages. Further, it explores how the arts may be the key to promoting twenty-first century skills of creative thinking and problemsolving. From this review, we hope that educators and policymakers will reconsider how arts education and arts-integrated learning can influence educational practices and policies.
\end{abstract}

\section{Keywords}

Art Education, Arts Integration, Education, Neuro-Education, Educational Policy, Pedagogy, Every Student Succeeds Act

\section{Introduction}

"Art is not the possession of the few who are recognized writers, painters, musicians; it is the authentic expression of any and all individuality".

-John Dewey, Moral Principles in Education

From the cave paintings of our earliest civilizations to their decorative dress, ritual dance, and storytelling, it is impossible to ignore the role of the arts as fundamental to the human experience. The arts define us as humans. Universal to human society, arts expressions are part of our cultural evolution and central to the cognitive development of our species. Turner (2006) argues that "art is an inevitable by-product of mimesis-a primordial, and truly human, cognitive adaptation that occurred very early in hominid prehistory and became the signature feature of the human mind" (p. 14). Through this lens, the arts are the essential platform upon which language and logic have developed. More than an anthropological sideshow, the arts constitute a direct connection between what we experience and who we are. 
Considering this fundamental role in the developing human mind and the growth of civilization, one must wonder why today we segregate the arts in our social structures and educational disciplines, making them apart from, instead of a part of, our everyday experiences. How did the "artful mind" become viewed as different from the "intellectual, academic mind"? How have the arts become marginalized in the way we educate our citizens? How did the visual and performing arts_ painting, sculpture, design, music, dance, theater, cinema and poetrybecome relegated to fringe subjects in modern views of school curricula?

The outline for this paper is as follows. First, the paper explores the political and social forces that have led to the well-documented narrowing of the curriculum, squeezing out arts programming in schools. While not intended to be an exhaustive literature review, this work then goes on to highlight important findings that correlate arts learning with biological changes as well as cognitive and academic advantages. Further, it explores how the arts may be the key to promoting twenty-first century skills of creative thinking and problem-solving. From this review, we hope that educators and policymakers will reconsider how arts education and arts-integrated learning can influence educational practices and policies.

\section{The Arts in American Schools}

The idea that the arts are disposable in schools seems to be a phenomenon with multiple conditions that have originated in the recent past. Historically, the arts played a central role in the education of our nation's youth. As early as the 1830 s and continuing to the 1880 s, drawing was taught in the belief that everyone should learn it as a means for refinement of manners and moral development (Efland, 1990). Horace Mann, an influential figure of that time who supported the common school as the link between children of privilege and the poor, claimed that developing children's hand-eye coordination through art was important to keeping "idle hands busy" (Efland, 1990: p. 146).

By the end of the 19th century, art curriculum appeared to diverge into two paths. In the progressive education movement, visual art and music were taught as distinct subjects with the idea that they would unleash the creativity inherent in every child and develop a sense of individual expression. The study of art reproductions in schools was propelled with the Picture Study Movement, which exposed students to art that was often religious or with a moral message (Efland, 1990). Arthur Wesley Dow's influential textbook, Composition: A Series of Exercises in Art Structure for the Use of Students and Teachers (Dow, 1902), introduced the elements and principles of art and design that remained central to art-curricular planning throughout the 20th century. At the same time, art training was viewed as utilitarian, with the goal of developing skills in the industrial workplace. Manual training, or what later was called industrial arts, was a response to the necessity for workers to acquire skills that would be immediately relevant to the needs of the workplace (Stankiewicz, 2001). At the turn of the 20th century, the progressive movement, fueled by the writings of the influential educator John Dewey, asserted that the arts were not just utilitarian but essential to promote critical thinking, active learning, and holistic preparation for real-world experiences (Kokkidou, 2013).

Keeping the movement toward inclusion of the arts alive, Bruner (1960) also maintained that education should be structured in ways that reflect real-world content, including the arts as a critical discipline of inquiry. Following such influential thinkers and in response to then-contemporary arts activism, President Kennedy established the Arts and Humanities Program in 1962 and created the National Endowment for the Arts, with the goal of offering arts opportunities for every citizen (Bauerlein \& Grantham, 2009). Despite those efforts and strong arts advocates, arts programs in schools have failed to serve all students - it is disappointing to note that by the 1970s, fewer than half of all school students were offered arts programs (Booth, 2013).

Unfortunately, the commitment to arts education in typical public elementary and secondary schools seems to have steadily declined. For example, the National Endowment for the Arts report indicates that since 1982, the percentage of adults ages 18 to 24 who participated in music class declined by more than a third; a mere 34 percent participated in a music class at any point in their education. The findings are even more dismal for participation in the visual arts, with 21 percent reporting having taken a visual arts class. Only 12.1 percent engaged in some dance experience, and a mere 5.9 percent participated in acting or theater class (National Endowment for the Arts, 2009). The report also notes regional disparities in access to arts opportunities. These results suggests that over time, the arts have been relegated to enrichment subjects most often offered to talented youth or children attending private or well-funded schools (Burnaford, Brown, Doherty, \& Mc Laughlin, 2007).

More recently, the arts have fallen victim to the well-documented narrowing of the curriculum, an unintended 
consequence of more than a decade of high-stakes testing and school accountability initiatives. And in this process of side-tracking (as "enrichment") such hardly ephemeral subjects as social studies, science, and the arts, we ask: what have we gained and what have we lost?

\section{Accountability and the Vanishing Arts}

The start of the accountability movement can first be traced to the call for back-to-basics following the 1967 launch of the Russian satellite, Sputnik, and the start of the race-to-space initiatives during the Cold War. This resulted in renewed interest for instruction in basic subjects - especially mathematics, reading, and science. However, many analysts cite the 1983 publication of $A$ Nation at Risk: The Imperative for Educational Reform (National Commission on Excellence in Education) as the impetus for the current state of high-stakes accountability. Comparing the academic performance of American students in basic subjects to those of other countries - especially Japan, Germany and Korea - the report stated that the nation's education systems were being "eroded by a rising tide of mediocrity that threatens our very future as a Nation and a people" (p. 112). It called for a renewed focus on the core subjects of math, science, and reading, recommending measurable academic performance standards and accountability among educators based on their students' achievement in the core subjects.

Since the publication of $A$ Nation at Risk (National Commission on Excellence in Education, 1983), public discourse on the need for education reform has centered on the notion that our country will lose economic strength because U.S. students are deficient in the knowledge of vital content - such as mathematics and science - compared to students from other countries. Indeed, the achievement gap between American and foreign students on international tests such as the Trends in Mathematics and Science Study (TIMSS) and the Programme for International Student Assessment (PISA) have been fodder for critics of our nation's education system. In 1998, the National Center for Education Statistics ranked U.S. students' performance in mathematics on the TIMSS in the bottom three out of 21 countries (Takahira, Gonzales, Frase, \& Salganik, 1998). Since that report, U.S. students have not shown measurable changes in achievement (Provasnik, Kastberg, Ferraro, Lemanski, Roey, \& Jenkins, 2012). Scores on the PISA were equally discouraging. According to the Pew Research Center, the 2012 PISA scores of 15-year olds in reading, mathematics, and science place American students in 35th place out of 64 countries (Desilver, 2015). National achievement test scores as measured by the National Assessment of Educational Progress (NAEP) also show stagnant performance and highlight the disparity of achievement based on students' race and income level. The most recent reports show that 40 percent of fourthgrade students and 33 percent of eighth-grade students perform at or above the proficient level in mathematics. In reading achievement, 36 percent of fourth-graders and 34 percent of eighth-graders scored at or above proficiency (National Assessment of Educational Progress, n.d.).

In response to the emphasis on preserving our global competitiveness and narrowing the achievement gap based on race and income, policymakers campaigned for robust school reforms and a federal role in school accountability. Thus the 2001 bipartisan No Child Left Behind Act (NCLB) focused squarely on school accountability based on reading and mathematics test scores. Schools became labeled as "failing" if they did not meet state accountability standards, and the failing label triggered a host of sanctions, which often resulted in replacing a school's teaching and administrative staff. Within this culture, it is no wonder that decisions to extend the amount of time in tested subjects and to reduce time in non-tested ones became common practice in schools across the country.

A 2007 survey of school districts conducted by the Center on Education Policy found that 62 percent of districts reported increased instructional time in reading and mathematics and 44 percent of districts reported reducing time spent on non-tested subjects including social studies, science, and the arts (McMurrer, 2007). More recently, Walker (2014) found that 81 percent of elementary teachers reported that time devoted to math and language arts instruction resulted in less time for other subjects. Sixty percent of middle school teachers and 54 percent of high school teachers reported the same curriculum narrowing. This and other unintended consequences of NCLB changed the face of education in public schools nationwide. While some of those changes produced important outcomes, such as the focus on the achievement gap based on income and race, overall, the law was criticized from a number of sectors.

One sharp critic, author and education advocate Ravitch (2010), points out that in addition to curriculum narrowing, even within the tested subjects much instructional time has been devoted to test preparation. Similar to 
many other advocates, she believes the testing culture has dominated classroom instruction, squeezing out teaching that fosters inquiry and the quest for knowledge. Moreover, states and districts participating in the federal funding competition, Race to the Top, further exacerbated the test-preparation trend by linking teacher evaluation with students' performance on yearly testing.

Among the non-tested subjects that lost instructional time in schools, the arts, in particular, have suffered significantly (Mishook \& Kornhaber, 2006). In 2010, the U.S. Department of Education reported that 40 percent of high schools did not require coursework in the arts for graduation (Bryant, 2015). A national survey conducted in 2011 found that half of all teachers reported that art and music classes were being eliminated in their schools (Walker, 2014).

There is conflicting information about the extent of arts programming in schools. A survey conducted by the National Center for Education Statistics during the 2009-2010 school year reported that 94 percent of elementary and secondary schools offered music and 83 percent offered visual arts, although the number of theater and dance programs offered were significantly lower, at 3 and 4 percent respectively (Parsad \& Spiegelman, 2012). Yet, some arts advocates question how participation in arts instruction was measured in this survey (Robelen, 2011). In some cases, a brief exposure to an art class during the year may have been reported as participation in arts instruction. Arts participation also may have been reported if students were exposed to an occasional assembly or an after-school or community-based program. Even if one assumes that the survey accurately portrays some level of appropriate arts instructional programs, Zubrzycki (2015a) points out that 1.3 million students still have no access to music education and about 4 million have no access to the visual arts. In another example, Zubrzycki (2015b) reports that in New Jersey, 97 percent of students were reported to have engaged in arts classes, while four out of five teachers in the same state report that class time for art instruction has diminished to prepare for state tests in reading and mathematics.

Most alarming, however, is that children attending schools in low-income neighborhoods are the least likely to receive arts instruction (Nathan, 2015). In New York City, for example, 20 percent of all schools lack a full or part time art teacher. A disproportionate 42 percent of those schools are located in two of the city's lower income neighborhoods (Strauss, 2014; Stringer, 2014). Moreover, most of the schools without arts and cultural organization partnerships and no dedicated arts rooms are located in neighborhoods with the lowest incomes (Stringer, 2014). O'Brien (2012) reports that in high-poverty schools, just 59 percent of schools have dedicated space for visual arts instruction compared to 76 percent in low-poverty schools.

A state-by-state analysis would likely show similar trends. In California, for example, arts programs have suffered deep budget cuts; in lower-income communities, some children receive arts programming only through non-profit organizations that provide after-school arts experiences (Torres, 2015). A recent survey of school administrators conducted in the Los Angeles Unified School District found that only 18 percent believed that their school offered quality arts instruction. Factors cited for the poor ratings include lack of funding, poor quality of arts facilities and materials, lack of appropriate teacher training and credentials, and insufficient time in the school schedule for arts instruction. Similar to many other large urban school districts, schools in the lowestincome neighborhoods were the least likely to have robust arts programming. Torres and Menezes (2015) point out that a key contributor to the disparity in arts experiences was that lower-income schools rely more heavily on district funding for arts programming, whereas schools in higher-income communities were able to garner outside resources to supplement arts education. A school that has access only to school-district resources may find little, if any, funding for arts programs; schools with access to outside funding streams have clear advantages to offer students during and outside-of-school-time arts experiences. The disparity in arts instruction between schools in high and lower-income communities is best summed up by U.S. Department of Education Secretary John King: "When you go many places in this country, it's hard to find an affluent suburban school that isn't offering art and music and technology. But then two miles away, sometimes two blocks away... you have a school that doesn't have any of that. We need to see that as a community we all have a stake in every child." (Klein, 2016, Leeway on Interventions, Para. 8).

\section{The Arts and Learning}

There is no doubt that students attending schools in low-income communities are largely not receiving sustained in-school or out-of-school arts instruction at a level comparable to their higher-income peers. Evidence shows that the children in low-income communities are paying a high price-in terms of academic and life achieve- 
ment—-for this disparity. Results from longitudinal studies by the National Endowment for the Arts found a significant relationship between arts education and various measures of academic achievement, especially for children in low-income communities (Catterall, Dumais, \& Hampden-Thompson, 2012). While correlational studies do not make the case for a causal relationship between the arts and learning, still, these findings provide important contributions by showing areas in which arts programming may be associated with better school outcomes. For example, Catterall and colleagues found that students from low-income schools who had higher levels of arts experiences than peers without the same experiences were more likely to complete high school, attain higher grade point averages, enroll in college, become more involved in community activism, and express greater interest in current affairs. These studies also highlight a sobering fact: students in low-income communities who attend schools that do not offer sufficient arts courses are five times more likely to drop out of high school than their counterparts who had multiple courses in the arts (Lynch, 2014).

Studies also show advantages for pre-school children from low-income families who are exposed to the arts. Brown, Benedett and Armistead (2010) examined the effects of arts instruction on assessments of school readiness and vocabulary development. They found that early learning of music, creative movement, and visual arts classes correlated with higher school-readiness skills. Students attending arts-enriched schools for two years showed greater gains than those with only one year of attendance. Both groups of students, those attending for one year and those attending for two years, demonstrated greater receptive vocabulary than counterparts at a comparison school without robust arts programs.

In a review of literature conducted for the National Endowment for the Arts, Menzer (2015) concludes that arts participation positively influences social and emotional skills in young children. Results from 18 empirical studies point to multiple benefits of arts participation in early childhood programming, including better social skills and emotional regulation - both strong predictors of later educational success.

Similarly, a study commissioned by the Turnaround Arts Initiative reported significant progress in academic achievement in mathematics and reading over a three-year span for students who had robust arts programming, compared to students in control schools with few arts experiences (Stoelinga, Silk, Reddy, \& Raham, 2015). Likewise, Helmrich (2010) found a correlation between formal instrumental music instruction and algebra achievement. Analyzing data from over 6000 students, findings show that students who had instructional music instruction performed better than their counterparts who did not have the same music instruction. Importantly, findings were consistent across demographics, such as race and income levels.

These studies are supported by evidence from community-based instrumental music programs for children attending school in low-income communities. For example, the OrchKids program, modeled after the Venezuelan orchestral training program El Sistema, offers year-round music programs in schools in low-income communities during and after school hours. Data from the program in Baltimore - the first OrchKids program in the U.S.- - shows stronger school attendance and higher reading proficiency compared to peers who did not participate (Robinson, 2014). A similar program, the Harmony Project, which provides music instruction for at-risk students in Los Angeles, reports impressive gains in academic and social skill development (BBC News, 2014; Wilson \& Harmony Project Team, 2015).

While these programs point to the role that arts can play in students' academic performance, it is important to note that many artists and advocates bristle at the notion that participation in the arts should be justified because they may improve educational goals. The "art for art's sake" mantra rightly points out that exposure to and participation in the arts enriches lives, and that alone is a reason for the arts to be central to a student's educational experience. Yet, it is hard to ignore research showing that participation in the arts is associated with a host of benefits, including non-academic skills such as collaboration, empathy, and critical thinking (Deasy, 2002).

\section{Arts Education and Transfer to Other Domains of Learning}

Arts advocates - perhaps stirred by the startling reduction in arts programming in schools in recent years and their belief in the benefits of arts participation - have turned to research in the domains of the learning sciences to show that the arts are far from a frills subject. They cite studies showing that the arts have value not only for the larger educational goal of improving student learning but also for cognitive and neurological development. For example, Dunbar (2008) found anatomic changes in the left frontal lobe and better symbolic reasoning in students who participated in performing arts programs (music and theater) compared with their counterparts who did not participate in performing arts. Hyde, Lerch, Norton, Forgeard, Winner, Evans and Schlaug (2009) found 
that just 15 months of instrumental music instruction for young children was associated with significant changes in brain structure in the auditory and motor areas, compared with a control group that received only singing and general music training.

Similarly, Kraus (2010) found that playing an instrument may assist in processing speech and interpreting voice changes that influence language comprehension. Also focused on the effects of music on cognitive skills, Forgeard, Winner, Norton and Schlaug (2008) found that students who had instrumental music training performed better on skills directly related to the training, such as fine motor skills. They also observed that students trained in playing an instrument showed better verbal reasoning and vocabulary compared with counterparts without such training. Examining the effects of music and theater training on long-term verbal memory, Jonides (2008) found that trained musicians, compared to non-musicians, demonstrated better long-term verbal memory and increased activation of the temporal lobe. Wandell, Dougherty, Ben-Shachar, Deutsch and Tsang (2008) found a correlation between training in the visual arts and improved reading ability, especially in phonological awareness; they also found biological changes within the corpus collosum, the structure that connects the left and right hemispheres of the brain.

These and other correlational studies show that some level of training in the arts is associated with improvement in certain cognitive and learning domains. As stated previously, while correlational studies do not claim causality, the emerging research on the arts and learning provides interesting insights into how arts instruction may transfer to academic learning. As Hetland, Winner, Veenema and Sheridan (2007) point out, there is scant causal evidence that the arts will raise standardized test scores in reading and math. However, they argue that the arts contribute to the development of more general thinking skills and dispositions that benefit school performance, such as envisioning, observing, reflecting, and engaging in multiple forms of expression.

Perkins (1994) and Arnheim (1969) also emphasize that visual-thinking skills acquired through the arts can promote new and creative ways of viewing the world. Drawing on research in cognition, Perkins (1994) presents arguments that endorse the use of the arts as a means for cultivating reflective thinking that motivates and engages students in all areas of learning. The benefits of looking at art include the development of dispositions of thinking, which he refers to as reflective intelligence - a set of skills, alertness to opportunities to utilize those skills, and the inclination to use them. Similarly, in the research compilation Critical Links: Learning in the Arts and Student Academic and Social Development, Deasy (2002) reports multiple studies that suggest the benefits of the arts for general learning in non-arts subjects, including self-motivation, social skills, tolerance, empathy, persistence and positive peer interaction.

Catterall (2002) highlights that the arts help not only in academic skills, but also with social skill development by increasing a student's ability to solve problems and reduce conflicts. Perhaps the benefits of the arts in promoting thinking dispositions and social development are further explanations for why students who participate in arts programs in schools demonstrate higher academic achievement and better school attendance than those who have little or no arts participation (Dwyer, 2011).

\section{The Arts as an Essential Pedagogical Technique: Arts Integration/Arts-Infused Teaching}

Considering the argument that the arts may improve students' general thinking skills and learning dispositions (persistence to task, more sustained attention, sharper skills in observation, richer tools for expression, and better social interactions), many advocates support the use of the arts as a teaching tool in non-arts subjects. Commonly referred to as arts integration, the process of teaching "with and through the arts" has gained momentum in schools across the country (Dwyer, 2011). Burnaford et al. (2007) describe arts integration as a way of promoting the transfer of knowledge and skills from arts to non-arts domains and helping students draw connections between different disciplines within school curricula. Using arts as a pedagogical tool also encourages collaboration among learners. Common to all arts-integration or arts-infused methods is the idea that non-arts content, such as language arts, social studies, math, and science, can be addressed at least in part through activities that incorporate the visual and performing arts.

A number of studies have linked arts integration to academic outcomes, such as achievement in reading and mathematics. The A+ Schools Program whole-school reform initiative in North Carolina (Fiske, 1999) and Oklahoma (Barry, 2010) reported achievement gains after schools instituted arts-integration programs. They also found strong community and teacher support for the impact of arts integration on general learning outcomes. 
In a quasi-experimental four-year study, Scripp, Burnaford, Vazequez, Paradis and Sienkiewicz (2013) compared six arts-integrated Chicago Public Schools to six demographically matched control schools. Relative to the control schools, the arts-integrated schools produced higher scores on state assessments and narrowed the achievement gap between high-and low-performing students. Similarly, the Mississippi Arts Commission Whole Schools Initiative conducted a four-year study involving over 5000 students in public and independent elementary schools. Results showed that arts-integrated schools, particularly those with the highest level of implementation, increased the percentage of students scoring "proficient" in literacy (Phillips, Harper, Lee, \& Boone, 2013). Results also corroborated previous findings that teachers believe arts integration leads to deeper learning, including making connections between new learning and previously learned concepts, stronger analytical skills, and enhanced ability to synthesize information into global conceptual thinking.

\section{The Arts and Student Engagement in Learning}

In addition to the academic benefits of the arts, research in student engagement in learning point to the efficacy of the arts to enhance students' motivation and enjoyment in learning. Disengagement in learning, especially among at-risk populations of students, was well documented by Finn (1993), whose longitudinal study showed a strong correlation between academic failure and assessments of students' disengagement in academic tasks. Klem and Connell (2004) suggest that about half of all students may be chronically disengaged by the time they reach high school. In a large longitudinal study of adolescent engagement, Blum (2005) shows a strong correlation of low levels of school connectedness with increased emotional stress and risk-taking behaviors. Clearly, school engagement is important not only for academic achievement but also for students' social-emotional wellbeing.

Scholarship in how the arts improve student engagement is encouraging. Researchers suggests that the arts (e.g. music and drama) provide a variety of activities that allow students to participate in schooling in a more meaningful and purposeful way. For example, Dawes and Larson (2011) report that after engaging in highquality arts programs, young adults report a deeper personal connection to the content they are learning. Other researchers suggest that students tend to view arts-integrated learning activities as more enjoyable than traditional activities, such as listening to lectures, reading from textbooks, completing worksheets, or writing reports (Smithrim \& Upitis, 2005; DeMoss \& Morris, 2002). For example, in a three-year study involving 55 schools using arts-integrated curricula compared to 35 schools that used non-arts-related special programming or no special programming, Smithrim and Upitis (2005) found significantly higher levels of student engagement in arts-integrated schools. Mathematics scores were also significantly higher in schools that used the arts curricula, which the authors attribute directly to higher engagement in school. As Hart and Albarracin (2009) point out, most students, especially those who lack an orientation toward academic learning, tend to show greater motivation when they perceive school activities as fun. Posner, Rothbart, Sheese and Kieras (2008) also established a link connecting the arts with greater motivation to learn and, therefore, more sustained engagement in learning tasks. Using surveys and EEG brain scans, the researchers tested various elements of arts learning and found that motivation sustains attention, and sustained attention improves cognition.

In addition to studying how school-based programs influence student engagement, several studies addressed how out-of-school arts experiences influenced school success and student motivation. Melnick, Witner and Strickland (2008) found that students with combined experiences of in-school and out-of-school arts programs performed better than students with only in-school experiences. They noted that students in rural areas were least likely to participate in arts experiences outside of school. In a similar longitudinal study, Martin et al. (2013) studied the role of in-school and out-of-school arts participation on students' academic and nonacademic outcomes. They found that arts activities conducted in school had a greater impact on academic performance, motivation, and engagement than out-of-school activities. They noted negative factors in motivation and nonacademic skills when students were required to pay for out-of-school arts activities.

Supporting these studies are riveting accounts of how the arts transform students' academic performance, increase their engagement in school, and provide emotional well-being (Deasy \& Stevenson, 2005). A recent interview with a seventh-grade student in a Baltimore City public school celebrated for its integration of the arts into all content sums up the experience of arts integration for many students: "When I learn through music, dance, and drawing, school becomes my happy place. And I think I learn more easily and remember what I have learned much better when teachers give us work that allows us to use different kinds of art" (Hardiman, 2015). 
Countless reports from teachers, as well as students, extol the benefits of embedding arts-based activities into core subjects, such as science, social studies, mathematics, and language arts. But it is important to be careful to identify the real benefit here: is it the entertainment value of the arts-in- fused curriculum, or do the arts actually trigger long-term retention of academic content?

\section{Arts Integration and Long-Term Retention of Content}

In a meta-analysis, Custers (2010) reviewed studies that analyzed students' retention of content learned in school. He reported that after two years, students retained about half of the academic content taught. Based on the idea that learning requires a certain number of repetitions for information to consolidate and move to long-term memory storage (Kandel, 2006), Hardiman $(2003 ; 2010)$ posited that arts-integrated instruction improves retention by prompting students to repeatedly rehearse and elaborate on academic content through various visual and performing-arts activities. In addition to rehearsal and elaboration, Hardiman and colleagues argued that the arts commonly involve a variety of other means of interacting with information that may likewise improve retention of content. They call these other means "memory effects"-areas that have been well-researched in the learning sciences over the last several decades (Hardiman, 2012; Rinne, Gregory, Yarmolinskaya, \& Hardiman, 2011). These "memory effects" include: 1) elaboration of content (Craik \& Tulving, 1975; Klein and Kihlstrom, 1986), which may include students writing dialogue or short stories to establish a stronger memory trace of the information learned; 2) generation of information (Slamecka \& Graff, 1978), such as producing information from a cue to encourage creative and divergent thinking; 3) enactment of content (Mohr, Engelkamp, \& Zimmer, 1989), which might involve theater-based activities or role-playing; 4) oral production (MacLeod, Gopie, Hourihan, Neary, \& Ozubko, 2010), such as generating content through the performing arts; 5) effort-after-meaning (Zaromb \& Roediger, 2009), which, for example, might include puzzling over the meaning of content as one might do in viewing a painting or reading a poem; 6) emotional arousal, central to all arts, which aids in information retrieval (Cahill \& McGaugh, 1995); and 7) pictorial representation of information (McBride \& Dosher, 2002), which has shown to produce greater memory than merely verbal input.

The authors (Hardiman, 2012; Rinne et al., 2011) argue that these memory effects enhance retention of academic content and that compared to traditional ways of teaching, the arts offer rich and diverse ways for incorporating these effects into instructional practice. To test this hypothesis, Hardiman et al. (2014) conducted a randomized control trial to examine if students who learned science content through arts-integrated instruction would retain the content better than students who learned the same content through conventional teaching.

\section{Proving Some Causal Connections: Science via the Arts}

Hardiman's research team at the Johns Hopkins University (JHU) School of Education developed closely matched arts-integrated and conventional versions of fifth-grade science units teaching the subject matter of ecology and astronomy. Four randomized groups of students received one body of content through an arts-integrated unit and a second body of content in a control unit that employed a traditional presentation. Curriculum-based assessments conducted at the conclusion of each of the units showed that from pre-testing to posttesting, students learned approximately the same amount of information regardless of the way they were taught. However, 10 weeks later, delayed test scores were significantly better for the arts-integrated condition. The study found a differential benefit when comparing students according to levels of proficiency in reading: students at the lower levels of achievement were the most likely to retain significantly more science content when given arts-integrated lessons than when given traditional science instruction.

In an expanded pilot study with 16 randomly assigned groups, the JHU research team tested four sets of artsintegrated treatment units matched to control units using four science content areas. Similar to findings from the original study, students performed better in delayed testing when taught using arts-integrated instruction, with students at the average and lower levels of achievement benefiting the most (Hardiman, 2015). These studies provided some preliminary causal connections between arts-enhanced learning and better memory for content. Findings also raised some interesting questions about whether or not learning through the arts transfers residual benefits.

Preliminary findings from the second study suggested the possibility that, once taught using arts-integrated instruction, students may later apply the strategies they learned, even during subsequent instruction through conventional methods (Hardiman, 2015). Data shows that students who experienced the arts-integrated units 
first performed significantly better in subsequent non-arts-infused units than students who had never experienced the arts-integrated approach.

While other factors such as familiarity with the unit structures may account for all students performing better the second time around, the findings nevertheless raise questions that bear further investigation. In particular, emerging research on creative thinking and problem-solving might connect learning with and through the arts as a fruitful alternative to conventional methods - as suggested by Dewey at the start of the 20th century.

\section{Creative Thinking and Problem Solving}

Hardiman (2012) and others suggest the possibility that the arts can influence not only areas of academic attainment and engagement in learning but also creative thinking and problem-solving, which have become a signature focus in the call for teaching 21 st century skills. Spearheaded by organizations such as the Partnership of 21st Century Schools, those skills essential to a successful career are collaboration, effective communication, innovative thinking, and creative problem-solving.

Yet, while educators are increasingly encouraged to design teaching to promote creative thinking, there is little consensus on what creativity means in an educational context. Broadly speaking, one of the most influential thinkers in the creativity domain, Robinson (2015), defines creative thinking as producing original ideas that have value. More specifically, creativity most often includes general processes such as divergent thinking, originality of response, fluency and elaboration in generating ideas, and utility of ideas generated (Kozbelt, Beghetto, \& Runco, 2010; Plucker, Beghetto, \& Dow, 2004).

Gregory, Hardiman, Yarmolinkaya, Rinne and Limb (2013) argue that within the educational context, creativity should be viewed as domain-specific rather than domain-general. In other words, rather than viewing a creative thinker as one who possesses certain inborn attributes that are generally applied in all aspects of thinking, creativity can be derived from and support knowledge within a given content domain (Sternberg, 2005). This assumes that creativity is not a fixed attribute, a special gift bestowed on a lucky few. Rather, this idea advances the notion that all students can demonstrate creative thinking, especially when they experience instruction that encourages them to find connections between disparate concepts, varied solutions to problems, and application of content in novel contexts (Weisberg, 2006; Plucker, Kaufman, \& Beghetto, 2015; Runco, 2014; Plucker, Kennedy, \& Dilley, 2015; Runco, 2014). Such strategies include collaboration on solving a problem having multipart tasks (Diehl \& Stroebe 1987), support for scaffolding content such as the use of graphic organizers to help students make connections among concepts (Sawyer \& Berson, 2004), and evaluating and revising ideas generated by others to aid in more original and fluent generation of one's own ideas (Lonergan, Scott, \& Mumford, 2004).

\section{The Arts and Creativity}

Beyond the hypothesis that exposure to the arts naturally recruits a variety of memory effects described earlier, many believe that teaching with and through the arts can be a powerful way to induce and empower students to think creatively and solve problems. Rostan (2010) argues that engaging in high-quality arts learning has been shown to develop creativity and provide an advantage for related forms of critical thinking. Csikszentmihalyi (1997) describes the special role the arts play in cognition by highlighting the emotional responses that the arts can engender, creating novel ways of thinking that "...break through the gray affectless daily routines and expand the range of what it means to be alive" (p. 36). He describes how the arts can create a state of deep concentration and a state of "flow" that leads to the "aha" of creative thinking. Posner and Patoine (2009) assert that the arts help to sustain attention, which they argue may improve learning by strengthening the brain's attentional networks.

Other researchers, such as Dunbar (2008), studied how the arts promote creativity and lead to anatomical changes in the brain. Comparing cognitive differences between students who participated in performing arts experiences with those who did not, results of fMRI studies showed that during tasks that required creative thinking, the performing arts group showed increased activity in the left frontal lobe, often associated with higherorder mental processing. Using standard measures of creative thinking, Dunbar also found that the students who had been engaged in the performing arts were more likely to generate creative ideas than peers who had no experiences in the performing-arts. Similarly, Limb and Braun (2008) found that spontaneous, creative improvisation activates different parts of the brain than memorized performance. They conducted fMRI studies of professional jazz musicians and found differences in brain activation while playing improvisational jazz compared to 
playing a memorized jazz music selection. Sawyer (2006) also found that students participating in improvisational jazz and theater groups produced more novel ideas than non-arts peers.

Supporting these studies in the performing arts, Welch, Barlex and Lim (2000) argue that sketching has been found to play a crucial role in generating and developing ideas, especially important in the language of design. They encourage the development of design drawing, which encourages students to construct and reconstruct different kinds of design ideas, freeing them from feeling that they have to produce a particular and expected kind of product. This is reminiscent of the utilitarian art training (Dow, 1902) that began in the United States around 1900 and sought to link skills acquired in school to the needs of the workplace.

These studies and a growing body of literature on the connection of arts and creative thinking suggest that experiences in the visual and performing arts, especially within content instruction, have the potential to help sustain attention, create emotional connections to content, foster the concentration leading to "aha" discoveries, and promote multiple, divergent solutions to problem-solving.

Within traditional content instruction, the arts have recently played an important role in the teaching of STEM subjects (science, technology, engineering, and mathematics). Adding the arts to the acronym, the STEAM movement has recently gained traction, likely in response to the often-espoused need for a more creatively productive workforce to increase U.S. global competitiveness. A recent bipartisan Congressional STEAM Caucus focused on the need for the interdisciplinary study of science, design, art, and education. John Maeda, president of the Rhode Island School of Design and co-host of the STEAM Caucus, describes the core of the STEAM movement: "In da Vinci's time when expertise in art and science had not yet matured to the polarized state in which they exist today, they coexisted naturally... it is clear to me that even current practices in scientific research have much to gain by involving artists in the process early and often. Artists serve as great partners in the communication of scientific research; moreover, they can serve as great partners in the navigation of the scientific unknown" (Maeda, 2013).

Likewise, Merten (2011) argues that science and the arts are a natural combination as both scientists and artists seek to create something new, whether new knowledge or a new product. The processes of that creation similarly involve seeking novel ways of understanding, exploring multiple solutions to a problem, trying new approaches, synthesizing multiple elements to create a larger whole, and envisioning what is not yet seen or discovered.

Many view the arts as a sort of springboard for imbuing traditionally taught STEM subjects with the creative application of knowledge that encourages innovation (Yusuf, 2007). This type of schooling has received renewed attention, as the drivers of our economic system call for a workforce that will keep our nation at the global forefront of invention, innovation, and initiative.

\section{Changing Times}

The STEAM movement is an example of changing philosophies in education; it acknowledges that new approaches to pedagogy must include interdisciplinary study based on inquiry, design thinking, and real-world problem-solving. This movement is driven, at least in part, by the national quest for global economic dominance, fueling the notion that our nation's K-12 schools and institutions of higher education must produce a larger pool of workers, especially engineers and scientists, who are not only subject experts but also innovative problem-solvers. To accomplish this, education systems must progress beyond the stringent accountability standards that have focused squarely on standardized testing in basic skills of reading and mathematics and consider broader domains of learning when assessing students' academic performance.

The latest iteration of the Elementary and Secondary Education Act, the Every Student Succeeds Act (ESSA), is a step forward in broadening the view of educational success and providing all students with a "well-rounded education". Significantly, with the enactment of ESSA, the arts are designated as core subjects and art educators can access federal funds to expand programming. Many education advocates hope that this new approach will address some of the unintended consequences of No Child Left Behind - most importantly, the narrowed curriculum that has led to diminishing arts programs in schools. The ESSA restores to states more control over standards and testing, which could encourage a more nimble education system by adopting alternative measures of student achievement. Depending on the will of state and local policy-makers, the doors are open for school accountability measures to include multiple metrics of school success and include participation in the visual and performing arts as a part of new measures of effective schooling (Blad, 2016). 
Educators know that what gets measured is what gets taught. Moreover, how we test largely drives how instruction is delivered. Broader, deeper, and more realistic school accountability measures - that involve a fresh focus on arts education and arts integration - could have profound implications for educational practices and policies. As part of this sea change in the field, policy-makers and educators would move away from a slavish reliance on multiple-choice tests to judge the quality of teaching and learning. Instead, new metrics could be designed to measure performance and competencies that promote creative problem solving, allowing students to use multiple, authentic ways to demonstrate mastery of content, skills and concepts.

Changes in assessment systems will encourage innovations such as inquiry-based learning, including the "Maker movement", where students are encouraged to tinker and build using simple materials of varying complexity from Legos to 3D printing software. The reform of assessment systems will also embolden teachers to move beyond the silos of compartmentalized subjects to build bridges across different curricular offerings.

In education, policy change is inevitably glacial. We do not change the philosophy or the practice until we absolutely have to. With only one-third of eighth-graders meeting proficiency standards in math and reading (U.S. Department of Education, n.d.), the time for change is now.

If we are really interested in global competitiveness, where will education reform come from, and who will drive it? Exogenous players will sometimes offer funding and often make demands for future outcomes. Meanwhile, teachers live in the here and now. They have to work with school leaders, school-district offices, community members, and parents to create and implement reform that is imperative and that serves our current students and our future citizens. This will require re-tooling areas such as curriculum, scheduling, and grouping. It will also require new modes of instructional delivery based on evidence-based practices. Teaching should take into account what is known from the learning sciences on how we best acquire, retain, and apply knowledge. Changes in schooling must also be driven by robust programs of teacher preparation, continuing education, and professional development. And helping teachers learn how to integrate the arts into content instruction must be included at every stage of teacher training. This will neither be accomplished within the status quo nor without a robust commitment to education research and development.

Far from being a fringe subject, one might view the arts as the cornerstone of better schooling. As Bush, Karp and Nadler (2015) point out, the countries that rank the highest in PISA testing — Japan, Hungary, and the Netherlands - are those that have mandatory arts programs.

From pre-school to adult learning, we know what the arts - more specifically, arts-infused teaching — can accomplish. It engages students by making them complicit in their own learning. Students follow structured, but never predefined, pathways to discover and weigh multiple solutions. Arts-integrated learning activities give students permission to be creative, but with a focus and a purpose. They remember more of what they learn because instead of memorizing content, they experience it. We believe these are fundamental 21 st century skills. And before we succeed in reforming the American education system, we must continue to pursue a goal that is within our grasp and facilitated through arts experiences: educating every child in the spirit of inquiry and joy.

\section{References}

Arnheim, R. (1969). Visual Thinking. London: Faber and Faber.

Barry, N. H. (2010). Oklahoma A+ Schools: What the Research Tells Us 2002-2007 (Volume 3). Edmond, OK: Oklahoma $\mathrm{A}+$ Schools/University of Central Oklahoma.

Bauerlein, M., \& Grantham, E. (2009). National Endowment for the Arts: A History, 1965-2008. National Endowment for the Arts. https://www.arts.gov/sites/default/files/nea-history-1965-2008.pdf

BBC News (2014). Musical Training “Can Improve Language and Reading”. BBC Health Online. http://www.bbc.com/news/health-28703013

Blad, E. (2016). ESSA Law Broadens Definition of School Success. Education Week. http://www.edweek.org

Blum, R. W. (2005). A Case for School Connectedness. Educational Leadership, 62, 16-20. http://eds.a.ebscohost.com

Booth, E. (2013). Teaching beyond and in between: Reframing a Flourishing Future for Arts Learning in Schools through Isotonic Instruction. Harvard Educational Review, 83, 120-126. http://dx.doi.org/10.17763/haer.83.1.x47778r716486237

Brown, E. D., Benedett, B., \& Armistead, M. E. (2010). Arts Enrichment and School Readiness for Children at Risk. Early Childhood Research Quarterly, 25, 112-124. http://dx.doi.org/10.1016/j.ecresq.2009.07.008

Bruner, J. S. (1960). On Learning Mathematics. The Mathematics Teacher, 53, 610-619. http://www.jstor.org/ 
Bryant, S. (2015). New NAMM Foundation Study Shows Parents and Teachers in Harmony about Students Learning Music. National Association of Music Merchants Foundation. https://www.nammfoundation.org/

Burnaford, G., Brown, S., Doherty, J., \& McLaughlin, J. (2007). Arts Integration Frameworks, Research \& Practice: A Literature Review. Washington DC: Arts Education Partnership. http://209.59.135.52/files/publications/arts integration book final.pdf

Bush, S. B., Karp, K. S., \& Nadler, J. (2015). Artist? Mathematician? Developing Both Enhances Learning! Teaching Children Mathematics, 22, 61-63. http://dx.doi.org/10.5951/teacchilmath.22.2.0061

Cahill, L., \& Mc Gaugh, J. L. (1995). A Novel Demonstration of Enhanced Memory Associated with Emotional Arousal. Consciousness and Cognition, 4, 410-421. http://dx.doi.org/10.1006/ccog.1995.1048

Catterall, J. S. (2002). The Arts and the Transfer of Learning. Critical Links: Learning in the Arts and Student Academic and Social Development (pp. 151-157). Washington DC: Arts Education Partnership.

Catterall, J. S., Dumais, S. A., \& Hampden-Thompson, G. (2012). The Arts and Achievement in At-Risk Youth: Findings from Four Longitudinal Studies (Research Report 55). National Endowment for the Arts. http://files.eric.ed.gov/fulltext/ED530822.pdf

Craik, F. I., \& Tulving, E. (1975). Depth of Processing and the Retention of Words in Episodic Memory. Journal of Experimental Psychology: General, 104, 268-294. http://dx.doi.org/10.1037/0096-3445.104.3.268

Csikszentmihalyi, M. (1997). Assessing Aesthetic Education: Measuring the Ability to "Ward off Chaos". Arts Education Policy Review, 99, 33-38. http://dx.doi.org/10.1080/10632919709600763

Custers, E. (2010). Long-Term Retention of Basic Science Knowledge: A Review Study. Advances in Health Sciences Education, 15, 109-128. http://dx.doi.org/10.1007/s10459-008-9101-y

Dawes, N. P., \& Larson, R. (2011). How Youth Get Engaged: Grounded-Theory Research on Motivational Development in Organized Youth Programs. Developmental Psychology, 47, 259-269. http://dx.doi.org/10.1037/a0020729

Deasy, R. J. (2002). Critical Links: Learning in the Arts and Student Academic and Social Development. Washington DC: Arts Education Partnership.

Deasy, R. J., \& Stevenson, L. M. (2005). Third Space: When Learning Matters. Washington DC: Arts Education Partnership. http://mediation.centrepompidou.fr

DeMoss, K., \& Morris, T. (2002). How Arts Integration Supports Student Learning: Students Shed Light on the Connections. Chicago, IL: Chicago Arts Partnerships in Education (CAPE).

Desilver, D. (2015). US Students' Improving-Slowly-in Math and Science, but Still Lagging Internationally. Pew Research Center. http://www.pewresearch.org/

Diehl, M., \& Stroebe, W. (1987). Productivity Loss in Brainstorming Groups: Toward the Solution of a Riddle. Journal of Personality and Social Psychology, 53, 497-509. http://dx.doi.org/10.1037/0022-3514.53.3.497

Dow, A. W. (1902). Composition: A Series of Exercises Selected from a New System of Art Education. Charlotte, NC: Baker and Taylor Company.

Dunbar, K. N. (2008). Arts Education, the Brain, and Language. In C. Asbury, \& B. Rich (Eds.), Learning Arts and the Brain: The Dana Consortium Report on Arts and Cognition (pp. 81-92). New York: The Dana Foundation.

Dwyer, M. C. (2011). Reinvesting in Arts Education: Winning America's Future through Creative Schools. President's Committee on the Arts and the Humanities. http://files.eric.ed.gov/fulltext/ED522818.pdf

Efland, A. (1990). A History of Art Education: Intellectual and Social Currents in Teaching the Visual Arts. New York: Teachers College Press.

Finn, J. D. (1993). School Engagement \& Students at Risk. Washington DC: National Center for Education Statistics.

Fiske, E. B. (1999). Champions of Change: The Impact of the Arts on Learning. Washington DC: Arts Education Partnership and President's Committee on the Arts and Humanities. http://files.eric.ed.gov/fulltext/ED435581.pdf

Forgeard, M., Winner, E., Norton, A., \& Schlaug, G. (2008). Practicing a Musical Instrument in Childhood Is Associated with Enhanced Verbal Ability and Nonverbal Reasoning. PLoS ONE, 3, e3566.

http://journals.plos.org/plosone/article?id=10.1371/journal.pone.0003566

http://dx.doi.org/10.1371/journal.pone.0003566

Gregory, E., Hardiman, M., Yarmolinskaya, J., Rinne, L., \& Limb, C. (2013). Building Creative Thinking in the Classroom: From Research to Practice. International Journal of Educational Research, 62, 43-50.

http://dx.doi.org/10.1016/j.ijer.2013.06.003

Hardiman, M. (2003). Connecting Brain Research with Effective Teaching: The Brain-Targeted Teaching Model. Lanham, MD: Rowman \& Littlefield Education. 
Hardiman, M. (2010). The Creative-Artistic Brain. In D. Sousa (Ed.), Mind, Brain, and Education: Neuroscience Implications for the Classroom (pp. 226-246). Bloomington, IN: Solution Tree Press.

Hardiman, M. (2012). The Brain-Targeted Teaching Model for 21st-Century Schools. Thousand Oaks, CA: Corwin Press.

Hardiman, M. (2015). The Effects of Arts-Integration on Retention of Content and Student Engagement. Grant No. R305A120451, Washington DC: Institute of Education Sciences, Johns Hopkins University School of Education.

Hardiman, M., Rinne, L., \& Yarmolinskaya, J. (2014). The Effects of Arts Integration on Long-Term Retention of Academic Content. Mind, Brain, and Education, 8, 144-148. http://www.researchgate.net/ http://dx.doi.org/10.1111/mbe.12053

Hart, W., \& Albarracín, D. (2009). The Effects of Chronic Achievement Motivation and Achievement Primes on the Activation of Achievement and Fun Goals. Journal of Personality and Social Psychology, 97, 1129-1141. http://dx.doi.org/10.1037/a0017146

Helmrich, B. H. (2010). Window of Opportunity? Adolescence, Music, and Algebra. Journal of Adolescent Research, 25, 557-577. http://jar.sagepub.com/content/25/4/557.full.pdf http://dx.doi.org/10.1177/0743558410366594

Hetland, L., Winner, E., Veenema, S., \& Sheridan, K. (2007). Studio Thinking: The Real Benefits of Visual Arts Education. New York: Teachers College Press.

Hyde, K., Lerch, J., Norton, A., Forgeard, M., Winner, E., Evans, A., \& Schlaug, G. (2009). Musical Training Shapes Structural Brain Development. The Journal of Neuroscience, 29, 3019-3025. http://www.jneurosci.org/content/29/10/3019.full http://dx.doi.org/10.1523/JNEUROSCI.5118-08.2009

Jonides, J. (2008). Musical Skill and Cognition. In C. Asbury, \& B. Rich (Eds.), Learning Arts and the Brain: The Dana Consortium Report on Arts and Cognition (pp. 11-16). New York: The Dana Foundation. http://w.aems-edu.org/PDFs/Learning_Arts and the Brain.pdf\#page=21

Kandel, E. R. (2006). In Search of Memory: The Emergence of a New Science of Mind. New York: W. W. Norton.

Klein, A. (2016). Education Department's Acting Chief Turns up Volume. Jacksonville, FL: Education Week. http://www.edweek.org

Klein, S. B., \& Kihlstrom, J. F. (1986). Elaboration, Organization, and the Self-Reference Effect in Memory. Journal of Experimental Psychology: General, 115, 26-38. http://dx.doi.org/10.1037/0096-3445.115.1.26

Klem, A. M., \& Connell, J. P. (2004). Relationships Matter: Linking Teacher Support to Student Engagement and Achievement. Journal of School Health, 74, 262-273. http://dx.doi.org/10.1111/j.1746-1561.2004.tb08283.x

Kokkidou, M. (2013). Critical Thinking and School Music Education: Literature Review, Research Findings, and Perspectives. Journal for Learning through the Arts, 9, 1-16. http://escholarship.org/

Kozbelt, A., Beghetto, R. A., \& Runco, M. A. (2010). Theories of Creativity. In J. C. Kaufman, \& R. J. Sternberg (Eds.), The Cambridge Handbook of Creativity (pp. 20-47). New York: Cambridge University Press. http://dx.doi.org/10.1017/CBO9780511763205.004

Kraus, N. (2010). Cognitive-Sensory Interaction in the Neural Encoding of Music and Speech. San Diego, CA: American Association for the Advancement of Science Annual Meeting.

Limb, C. J., \& Braun, A. R. (2008). Neural Substrates of Spontaneous Musical Performance: An fMRI Study of Jazz Improvisation. PLoS ONE, 3, e1679. http://dx.doi.org/10.1371/journal.pone.0001679

Lonergan, D. C., Scott, G. M., \& Mumford, M. D. (2004). Evaluative Aspects of Creative Thought: Effects of Appraisal and Revision Standards. Creativity Research Journal, 16, 231-246. http://dx.doi.org/10.1080/10400419.2004.9651455

Lynch, R. (2014). Arts Education Transforms Societies. New York: Huffington Post, Arts \& Culture. http://www.huffingtonpost.com

MacLeod, C., Gopie, N., Hourihan, K., Neary, K., \& Ozubko, J. (2010). The Production Effect: Delineation of a Phenomenon. Journal of Experimental Psychology: Learning, Memory, and Cognition, 36, 671-685. http://dx.doi.org/10.1037/a0018785

Maeda, J. (2013). Artists and Scientists: More Alike Than Different. Scientific American. http://blogs.scientificamerican.com/

Martin, A., Mansour, M., Anderson, M., Gibson, R., Liem, G., \& Sudmalis, D. (2013). The Role of Arts Participation in Students' Academic and Nonacademic Outcomes: A Longitudinal Study of School, Home, and Community Factors. Journal of Educational Psychology, 105, 709-727. http://dx.doi.org/10.1037/a0032795

McBride, D. M., \& Dosher, B. A. (2002). A Comparison of Conscious and Automatic Memory Processes for Picture and Word Stimuli: A Process Dissociation Analysis. Consciousness and Cognition, 11, 423-460. 
http://dx.doi.org/10.1016/S1053-8100(02)00007-7

McMurrer, J. (2007). Choices, Changes, and Challenges: Curriculum and Instruction in the NCLB Era. Washington DC: Center on Education Policy.

Melnick, S. A., Witmer, J. T., \& Strickland, M. J. (2008). Cognition and Student Learning through the Arts. Arts Education Policy Review, 112, 154-162. http://dx.doi.org/10.1080/10632913.2011.566100 http://digitalcommons.uconn.edu/cgi/viewcontent.cgi?article=1013\&context=nera 2008

Menzer, M. (2015). The Arts in Early Childhood: Social and Emotional Benefits of Arts Participation. Washington DC: National Endowment for the Arts. www.arts.gov

Merten, S. (2011). Enhancing Science Education through Art. Science Scope, 35, 31-35. http://www.jstor.org/stable/43183128

Mishook, J. J., \& Kornhaber, M. L. (2006). Arts Integration in an Era of Accountability. Arts Education Policy Review, 107, 311. http://eric.ed.gov http://dx.doi.org/10.3200/AEPR.107.4.3-11

Mohr, G., Engelkamp, J., \& Zimmer, H. D. (1989). Recall and Recognition of Self-Performed Acts. Psychological Research, 51, 181-187. http://dx.doi.org/10.1007/BF00309146

Nathan, J. (2015). Advocating for Arts Education. Jacksonville, FL: Education Week. http://blogs.edweek.org/

National Assessment of Educational Progress (n.d.). 2015 Mathematics \& Reading Assessments. The Nation's Report Card. http://www.nationsreportcard.gov/reading math_2015

National Commission on Excellence in Education (1983). A Nation at Risk: The Imperative for Educational Reform. The Elementary School Journal, 84, 112-130. http://www.jstor.org/stable/1001303

National Endowment for the Arts (2009). 2008 Survey of Public Participation in the Arts. Research Report No. 49. https://www.arts.gov/sites/default/files/2008-SPPA.pdf

O'Brien, A. (2012). Can Arts Education Help Close the Achievement Gap? Alexandria, VA: Learning First Alliance. http://www.learningfirst.org/can-arts-education-help-close-achievement-gap

Parsad, B., \& Spiegelman, M. (2012). Arts Education in Public Elementary and Secondary Schools: 1999-2000 and $2009-10$. Report NCES 2012-014. http://nces.ed.gov/pubs2012/2012014rev.pdf

Perkins, D. N. (1994). The Intelligent Eye: Learning to Think by Looking at Art (Vol. 4). Los Angeles, CA: Getty Publications.

Phillips, J., Harper, J., Lee, K., \& Boone, E. (2013). Arts Integration and the Mississippi Arts Commission's Whole Schools Initiative. http://www.mswholeschools.org

Plucker, J. A., Beghetto, R. A., \& Dow, G. T. (2004). Why Isn’t Creativity More Important to Educational Psychologists? Potentials, Pitfalls, and Future Directions in Creativity Research. Educational Psychologist, 39, 83-96. http://dx.doi.org/10.1207/s15326985ep3902_1

Plucker, J. A., Kaufman, J. C., \& Beghetto, R. A. (2015). What We Know about Creativity. P21 Research Series, Washington DC: Partnership for 21st Century Learning. http://www.p21.org/our-work/4cs-research-series/creativity

Plucker, J. A., Kennedy, C., \& Dilley, A. (2015). What We Know about Collaboration. P21 Research Series, Washington DC: Partnership for 21st Century Skills. http://www.p21.org/our-work/4cs-research-series/collaboration

Posner, M. I., \& Patoine, B. (2009). How Arts Training Improves Attention and Cognition. Cerebrum, 2-4. https://www.researchgate.net/

Posner, M., Rothbart, M. K., Sheese, B. E., \& Kieras, J. (2008). How Arts Training Influences Cognition. In C. Asbury, \& B. Rich (Eds.), Learning Arts and the Brain: The Dana Consortium Report on Arts and Cognition (pp. 1-10). New York: The Dana Foundation.

Provasnik, S., Kastberg, D., Ferraro, D., Lemanski, N., Roey, S., \& Jenkins, F. (2012). Highlights from TIMSS 2011: Mathematics and Science Achievement of US Fourth-and Eighth-Grade Students in an International Context. Report 2013-009, National Center for Education Statistics.

Ravitch, D. (2010). The Life and Death of the Great American School System: How Testing and Choice Are Undermining Education. New York: Perseus.

Rinne, L., Gregory, E., Yarmolinskaya, J., \& Hardiman, M. (2011). Why Arts Integration Improves Long-Term Retention of Content. Mind, Brain, and Education, 5, 89-96. http://dx.doi.org/10.1111/j.1751-228X.2011.01114.x

Robelen, E. (2011). White House Panel Calls for "Reinvesting" in Arts Education. Jacksonville, FL: Education Week. http://blogs.edweek.org/edweek/curriculum/2011/05/white house advisory panel hig.html

Robinson, K., \&Aronica, L. (2015). Creative Schools: The Grassroots Revolution That's Transforming Education. New 
York: Viking, Penguin Random House LLC.

Robinson, L. (2014). BSO OrchKids Grows Future Musicians. http://www.wbaltv.com/news/bso-orchkids-grows-future-musicians/30443244

Rostan, S. M. (2010). Studio Learning: Motivation, Competence, and the Development of Young Art Students' Talent and Creativity. Creativity Research Journal, 22, 261-271. http://dx.doi.org/10.1080/10400419.2010.503533

Runco, M. A. (2014). Creativity: Theories and Themes: Research, Development, and Practice. San Diego, CA: Academic Press.

Sawyer, R. K. (2006). Educating for Innovation. Thinking Skills and Creativity, 1, 41-48. http://dx.doi.org/10.1016/j.tsc.2005.08.001

Sawyer, R. K., \& Berson, S. (2004). Study Group Discourse: How External Representations Affect Collaborative Conversation. Linguistics and Education, 15, 387-412. http://dx.doi.org/10.1016/j.linged.2005.03.002

Scripp, L., Burnaford, G., Vazquez, O., Paradis, L., \& Sienkiewicz, F. (2013). Partnerships in Arts Integration Research Final Reports. Washington DC: Arts Education Partnership. http://www.artsedsearch.org

Slamecka, N. J., \& Graf, P. (1978). The Generation Effect: Delineation of a Phenomenon. Journal of Experimental Psychology: Human Learning and Memory, 4, 592-604. http://dx.doi.org/10.1037/0278-7393.4.6.592

Smithrim, K., \& Upitis, R. (2005). Learning through the Arts: Lessons of Engagement. Canadian Journal of Education/Revue canadienne de l'education, 28, 109-127. http://www.jstor.org/stable/1602156

http://dx.doi.org/10.2307/1602156

Stankiewicz, M. A. (2001). Roots of Art Education Practice: Art Education in Practice Series. Worcester, MA: Davis Publications Inc.

Sternberg, R. J. (2005). Creativity or Creativities? International Journal of Human-Computer Studies, 63, 370-382. http://dx.doi.org/10.1016/j.ijhcs.2005.04.003

Stoelinga, S. R., Silk, Y., Reddy, P., \& Rahman, N. (2015). Turnaround Arts Initiative: Summary of Key Findings. President's Committee on the Arts and the Humanities. http://pcah.gov/sites/default/files/Turnaround\%20Arts\%20Phase\%201\%20Final\%20Evaluation_Summary.pdf

Strauss, V. (2014). Why the Kids Who Most Need Arts Education Aren’t Getting It. The Washington Post. https://www.washingtonpost.com

Stringer, S. (2014). State of the Arts: A Plan to Boost Arts Education in New York City Schools. Bureau of Policy and Research Report, NYC Comptroller, New York: The Office of the New York City Comptroller.

http://comptroller.nyc.gov/wp-content/uploads/documents/State_of_the_Arts.pdf

Takahira, S., Gonzales, P., Frase, M., \& Salganik, L. H. (1998). Pursuing Excellence: A Study of US Twelfth-Grade Mathematics and Science Achievement in International Context. Initial Findings from the Third International Mathematics and Science Study. NCES 98-049, Washington DC: US Department of Education, National Center for Education Statistics, US Government Printing Office.

Torres, Z. (2015). Arts Education in All Schools Needs to Be a Priority and Better Funded, Advocates Say. Los Angeles, CA: The Los Angeles Times. http://www.latimes.com

Torres, Z., \& Menezes, R. (2015). Only 35 L.A. Public Schools Get an A in Supporting the Arts. Los Angeles, CA: The Los Angeles Times. http://www.latimes.com

Turner, M. (2006). The Artful Mind: Cognitive Science and the Riddle of Human Creativity. Oxford: Oxford University Press. http://dx.doi.org/10.1093/acprof:oso/9780195306361.001.0001

US Department of Education (n.d). Institute of Education Sciences. National Center for Education Statistics.

Walker, T. (2014). The Testing Obsession and the Disappearing Curriculum. The National Education Association Today. http://neatoday.org/

Wandell, B., Dougherty, R., Ben-Shachar, M., Deutsch, G., \& Tsang, J. (2008). Training in the Arts, Reading, and Brain Imaging. In C. Asbury, \& B. Rich (Eds.), Learning Arts and the Brain: The Dana Consortium Report on Arts and Cognition (pp. 51-59). New York: The Dana Foundation.

Weisberg, R. W. (2006). Expertise and Reason in Creative Thinking: Evidence from Case Studies and the Laboratory. In J. Baer (Ed.), Creativity and Reason in Cognitive Development (pp. 7-42). New York: Cambridge University Press. http://dx.doi.org/10.1017/CBO9780511606915.003

Welch, M., Barlex, D., \& Lim, H. S. (2000). Sketching: Friend or Foe to the Novice Designer? International Journal of Technology and Design Education, 10, 125-148. http://dx.doi.org/10.1023/A:1008991319644

Wilson, K., \& Harmony Project Team (2015). Harmony Project Annual Report. The Harmony Project. 
Yusuf, S. (2007). From Creativity to Innovation. Washington DC: The World Bank.

Zaromb, F. M., \& Roediger, H. L. (2009). The Effects of "Effort after Meaning" on Recall: Differences in within- and between-Subjects Designs. Memory and Cognition, 37, 447-463. http://dx.doi.org/10.3758/MC.37.4.447

Zubrzycki, J. (2015a). National Endowment for the Arts Focuses on Equity in Education. Jacksonville, FL: Education Week. http://blogs.edweek.org/

Zubrzycki, J. (2015b). Testing Encroaches on Arts Time, New Jersey Educators Report. Jacksonville, FL: Education Week. http://blogs.edweek.org/

\section{Submit or recommend next manuscript to SCIRP and we will provide best service for you:}

Accepting pre-submission inquiries through Email, Facebook, LinkedIn, Twitter, etc.

A wide selection of journals (inclusive of 9 subjects, more than 200 journals)

Providing 24-hour high-quality service

User-friendly online submission system

Fair and swift peer-review system

Efficient typesetting and proofreading procedure

Display of the result of downloads and visits, as well as the number of cited articles

Maximum dissemination of your research work

Submit your manuscript at: http://papersubmission.scirp.org/ 